\title{
Działalność Fundacji Pomocy Humanitarnej Redemptoris Missio odpowiedzią na wyzwania encykliki Jana Pawła II
}

\author{
Humanitarian Aid Foundation „Redemptoris missio" 's activity as a response to the call \\ of the encyclical of John Paul II
}

Fundacja Pomocy Humanitarnej Redemptoris Missio założona została w 1992 r. w Poznaniu. Celem jej powstania było stworzenie fachowego zaplecza medycznego dla ośrodków misyjnych, w których pracują polscy misjonarze.

Strategia działania Fundacji oparta jest na statucie ${ }^{1}$, ale encyklika Jana Pawła II o stałej aktualności posłania misyjnego, odcisnęła na nim wyraźne piętno. Fundacja, pozostając w harmonii z nazwą tego ważnego dokumentu Magisterium Kościoła, stara się realizować jego zalecenia. O czym traktuje dokument i w jakich obszarach jest dla niej przewodnikiem?

\section{WYBRANE ZAGADNIENIA ENCYKLIKI REDEMPTORIS MISSIO}

Papież Jan Paweł II już we wprowadzeniu podkreśla, że misja Odkupiciela mimo dwóch tysięcy lat chrześcijaństwa nadal nie została wypełniona. Ponad połowa żyjących na ziemi ludzi nie słyszała jeszcze o Chrystusie, ale tęskni za Nim i próbuje szukać, bo każda istota ludzka potrzebuje Jego daru odkupienia i Dobrej Nowiny. Liczba tych, którzy Go nie znają stale się powiększa, co czyni wezwanie Chrystusa: Idźcie na cały świat i głoście Ewangelię wszelkiemu stworzeniu (Mk 16,15), jeszcze bardziej przynaglającym.

Do przepowiadania Ewangelii i dawania świadectwa jest powołany, na mocy Chrztu świętego każdy chrześcijanin, niezależnie od pełnionej przez siebie funk-

${ }^{1}$ Por. Statut Fundacji Pomocy Humanitarnej "Redemptoris Missio”, “Annales Missiologici" 11 (2000) s. 314-319. 
cji, stanu, płci². Mimo napotykanych trudności nie wolno nam zaniedbywać obowiązku głoszenia (por. RMis 35,36$)^{3}$. Nikt nie ma prawa przywłaszczać, czy zatajać prawdy, jaką Bóg objawił o sobie. Chrystus jest odpowiedzią na wiele pytań: o sens istnienia, cierpienia, miłości, przeznaczenia, czy wewnętrznej tęsknoty. Tylko Chrystus i Jego miłość, jaką darzy dziecko Boże, daje prawdziwe wyzwolenie (por. RMis 11). W obliczu uciemiężenia, jakiego doznaje tyle narodów na ziemi, należy spieszyć, by jak najszybciej poznały one tę prawdę.

W sposób szczególny powołani do głoszenia Ewangelii są świeccy ${ }^{4}$ Mimo, iż najcenniejszym owocem Kościoła są misjonarze na całe życie, to ogromną rolę we współczesnej ewangelizacji odegrać mogą ci, którzy spontanicznie odpowiedzą na ten apel Chrystusa. Południe i Wschód potrzebują nowych "robotników", którzy dając świadectwo prawdziwie chrześcijańskiego życia, pociagną do Jezusa tych, którzy jeszcze Go nie znają.

Kościół, jako sakrament zbawienia, czy posłany przez niego misjonarz, nie rozwiąże wszystkich problemów i nie uzdrowi w cudowny sposób wszelkich bolączek ludu, któremu głosi Dobrą Nowinę. Dąży on raczej do prawdziwego rozwoju człowieka i udzielenia mu wielowymiarowej pomocy, bo tylko tą droga można walczyć z ubóstwem czy gospodarczym zacofaniem (por. RMis 56). To człowiek, a nie pieniądz czy osiągnięcia nauki i techniki, może zmienić przyszłość swojego narodu (por. RMis 58). Dlatego częścią ewangelizacji są zakładane przez misjonarzy szkoły, szpitale, hospicja, sierocińce, a nawet miejsca pracy. Misja Odkupiciela, którą stara się kontynuować Kościół stawia na człowieka, jako protagonistę rozwoju (RMis 58).

Ewangelia w pierwszej kolejności głoszona jest ubogim. Poprzez misjonarza Kościół dzieli się z potrzebującymi wszelkimi darami. Aby odczuli oni miłość Chrystusa potrzebne są ziemskie ostaje miłosierdzia: placówki oświatowe, zdrowotne, leprozoria. Ponadto Jan Paweł II wzywa w 72 numerze swojej encykliki, do zrzeszania się, udziału w ruchach, chrześcijańskich organizacjach wolontariatu międzynarodowego, stowarzyszeniach laikatu misyjnego, które włączają się w misje ad gentes.

Ważnym zadaniem jest troska o misjonarzy, o potrzeby materialne, które uskuteczniają czy też umożliwiają działalność misyjną w odległych zakątkach świata. To element bez którego nie utrzymałyby się charytatywne przedsięwzięcia, prowadzone przez misjonarzy dla ubogich społeczeństw. Nie wolno zaniechać wysiłków mających na celu troskę o budzenie powołań, w sposób szczególny wśród młodzieży i w rodzinach (por. RMis 80$)^{5}$.

\footnotetext{
${ }^{2}$ Por. Jan Paweł II, Christifideles laici, 15.

${ }^{3}$ Por. W. Kluj, Określenie działalności misyjnej w "Redemptoris missio”, AMis 11 (2000), s. $142-143$.

${ }^{4}$ Por. Jan Paweł II, Christifideles laici, 33.

${ }^{5}$ Por. F. Jabłoński, Nauczanie Jana Pawła II o misyjnej naturze Kościoła w oparciu o orędzia na Światowy Dzień Misyjny (1979-1999), AMis 11 (2000), s. 198-201.
} 
Papież zwraca uwagę na nowe formy współpracy misyjnej. Podkreśla, że bezpośrednia znajomość życia misyjnego i nowych wspólnot chrześcijańskich może wzbogacić $i$ ożywić wiarę. Zastuguje na pochwate odwiedzanie placówek misyjnych, zwłaszcza przez młodych, któzy udaja się tam, by stużyć i doświadczyć prawdziwego życia chrześcijańskiego. (RMis 82). W odpowiedzi na te liczne apele i wskazówki powstała organizacja działająca w środowisku osób świeckich, której nazwa zaczerpnięta została bezpośrednio z tytułu encykliki: Redemptoris Missio.

\section{ENCYKLIKA A DZIAŁALNOŚĆ FUNDACJI ORGANIZOWANIE POMOCY MEDYCZNEJ I MATERIALNEJ}

Fundacja Pomocy Humanitarnej Redemptoris Missio podejmuje różnorodne przedsięwzięcia, aby poprawić los pozbawionych opieki medycznej mieszkańców najuboższych regionów świata. Jej działalność opisać można na czterech płaszczyznach: wyprawy medyczne i praktyki studenckie, wysyłka paczek, budowa Centrum Zdrowia w Kiabakari oraz inne akcje.

1. Wyprawy medyczne do krajów rozwijających się

W ciągu dziewiętnastu lat zorganizowanych zostało aż 60 wypraw medycznych i praktyk studenckich ${ }^{6}$. Najczęstszym ich celem była Zambia (14 wypraw), Indie (12 wypraw) i Tanzania (9). Jedną misję skierowano do Ameryki Środkowej, dwie na Oceanię, ale dominującym beneficjentem pomocy medycznej była Afryka i Azja. Kontynent azjatycki był celem jednej piątej wszystkich wyjazdów. Do największych przedsięwzięć w historii wypraw medycznych należała z pewnością Operacja Bangassu 2002, czyli miesięczna misja ośmiu poznańskich chirurgów w Republice Środkowej Afryki.

Łącznie, (do końca grudnia 2010 r.) dzięki Fundacji, do krajów rozwijających się z pomocą medyczna, udało się 125 osób. Najliczniejszą grupę wolontariuszy stanowili studenci, którzy w miesiącach wakacyjnych chętnie korzystali z możliwości odbycia praktyk zawodowych w ośrodkach misyjnych. Niektóre z projektów realizowane były we współpracy z Ministerstwem Spraw Zagranicznych. Niemniej ważne były interwencje lekarzy specjalistów: wspomnianych już chirurgów, okulistów, dentystów wielokrotnie kierowanych m.in. do Ośrodka Trędowatych w Puri.

\footnotetext{
${ }^{6}$ Szczegóły prezentują tabela nr 1 i rycina $\mathrm{nr} 1$.
} 
Tab. 1. Wyprawy medyczne i praktyki studenckie w latach 1991-2010; udział w wyjazdach poszczególnych grup zawodowych.

\begin{tabular}{|c|c|c|c|c|c|c|}
\hline Rok & Kontynent & Kraj & Studenci & Lekarze & Pielegniarki & inni \\
\hline 1991 & Azja & Indie & \begin{tabular}{r|}
6 \\
\end{tabular} & & & \\
\hline \multirow{2}{*}{1993} & Azja & Indie & 3 & 1 & & producent filmowy \\
\hline & Azja & Indie & 3 & & & \\
\hline \multirow{4}{*}{1996} & \begin{tabular}{|l|} 
Afryka \\
\end{tabular} & Zambia & 1 & & & \\
\hline & \begin{tabular}{|l|} 
Afryka \\
\end{tabular} & Kamerun & 1 & & & \\
\hline & \begin{tabular}{|l|} 
Afryka \\
\end{tabular} & Zambia & & 1 & & \\
\hline & Oceania & Papua-N.Gwinea & & 1 & & \\
\hline \multirow{3}{*}{1997} & Afryka & Zambia & 1 & & & \\
\hline & Afryka & Uganda & 1 & & & \\
\hline & Azja & Indie & & 4 & & \\
\hline \multirow{2}{*}{1998} & Afryka & Zambia & & 1 & & \\
\hline & Afryka & Zambia & & & 1 & \\
\hline \multirow{5}{*}{1999} & Azja & Indie & 1 & 3 & & \\
\hline & \begin{tabular}{|l|} 
Afryka \\
\end{tabular} & Zambia & & 1 & & \\
\hline & \begin{tabular}{|l|} 
Azja \\
\end{tabular} & Indie & 2 & & & \\
\hline & Oceania & Papua-N.Gwinea & & 2 & & \\
\hline & Afryka & Zambia & 2 & & & \\
\hline 2000 & Afryka & Tanzania & 4 & 1 & & \\
\hline \multirow{6}{*}{2001} & \begin{tabular}{|l|} 
Afryka \\
\end{tabular} & Zambia & & 2 & & \\
\hline & Afryka & Zambia & & & 1 & \\
\hline & Afryka & Senegal & & & 1 & \\
\hline & Azja & Indie & 3 & 1 & & \\
\hline & Afryka & Zambia & 1 & & & \\
\hline & Oceania & Papua-N. Gwinea & & 1 & & \\
\hline \multirow{7}{*}{2002} & Afryka & Republika Sr. Afrylki & & 8 & & reporter TVN \\
\hline & Oceania & Papua-N. Gwinea & 1 & & & \\
\hline & \begin{tabular}{|l|} 
Afryka \\
\end{tabular} & Malawi & 2 & & & \\
\hline & Afryka & Zambia & 3 & & & \\
\hline & Afryka & Uganda & 4 & & & \\
\hline & Afryka & Kenia & 3 & & & \\
\hline & \begin{tabular}{|l|} 
Afryka \\
\end{tabular} & Uganda i Kenia & & & & 3 wolont. SWM \\
\hline \multirow{4}{*}{2003} & Afryka & Zambia & 5 & 1 & & \\
\hline & \begin{tabular}{|l|} 
Afryka \\
\end{tabular} & Malawi & 1 & & & \\
\hline & Azja & Indie & & 3 & & \\
\hline & Afryka & Zambia & & & 2 & \\
\hline \multirow{2}{*}{2004} & Azja & Indie & 4 & & & \\
\hline & \begin{tabular}{|l|} 
Afryka \\
\end{tabular} & Kamerun & 1 & & & \\
\hline \multirow{4}{*}{2005} & Afryka & Sierra Leone & & 1 & & \\
\hline & Azja & Indie & 2 & & & \\
\hline & \begin{tabular}{|l|} 
Afryka \\
\end{tabular} & Uganda & 1 & 1 & & \\
\hline & Azja & Indie & & 1 & & \\
\hline \multirow{5}{*}{2006} & \begin{tabular}{|l|} 
Afryka \\
\end{tabular} & Tanzania & 3 & & & \\
\hline & Azja & Indie & 2 & & & \\
\hline & Afryka & Tanzania & & 1 & & \\
\hline & Ameryka Śr. & Jamajka & & 1 & & \\
\hline & Afryka & Kamerun & & 1 & & \\
\hline
\end{tabular}




\begin{tabular}{|c|c|c|c|c|c|c|}
\hline \multirow{3}{*}{2007} & Afryka & Tanzania & & 1 & & \\
\hline & Afryka & Uganda & 2 & & & \\
\hline & Afryka & Kamerun & & 1 & & \\
\hline \multirow{4}{*}{2008} & Afryka & Tanzania & & & & spec. ZP \\
\hline & Afryka & Tanzania & & 1 & & \\
\hline & Afryka & Tanzania & & 1 & & \\
\hline & Afryka & Kenia & 2 & & & \\
\hline \multirow{3}{*}{2009} & Afryka & Kamerun & & 1 & & polożna \\
\hline & Afryka & Uganda & 1 & & & \\
\hline & Afryka & Tanzania & 1 & & & \\
\hline \multirow{4}{*}{2010} & Afryka & Tanzania & & & 1 & \\
\hline & Afryka & Zambia & 1 & & & \\
\hline & Afryka & Namibia & & & 1 & \\
\hline & Afryka & Kenia & & 1 & & \\
\hline
\end{tabular}

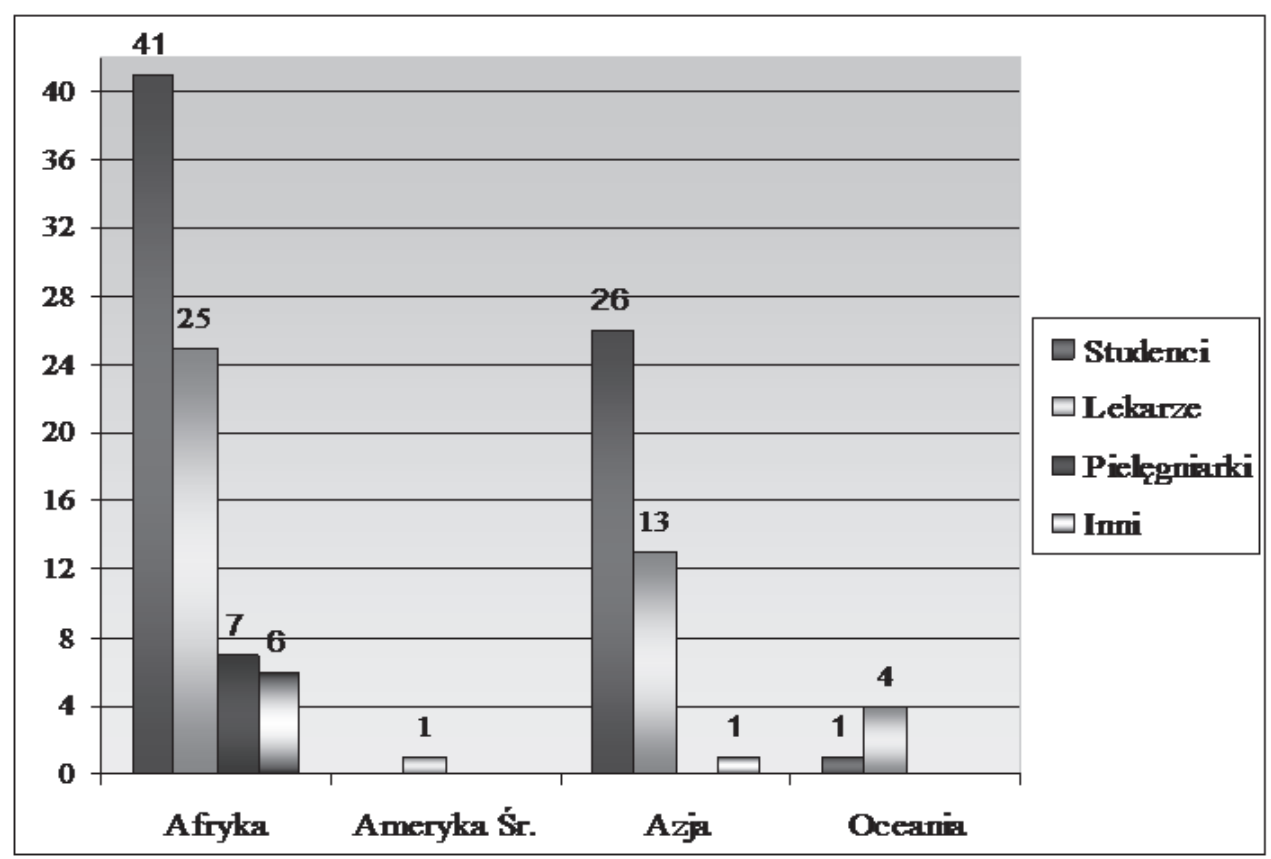

Ryc. 1. Liczba uczestników wypraw organizowanych przez Fundację w latach 1991-2010 według kontynentów.

\section{Pomoc materialna}

Fundacja od początku swego istnienia stara się wspomagać misjonarzy na całym świecie. Realizuje to poprzez wsparcie materialne, a także od lutego $1998 \mathrm{r}$., poprzez planowaną wysyłkę paczek z lekami i materiałami medycznymi, czasem sprzętem czy żywnością. W ciągu kilkunastu lat działalności wsparła finansowo 
wiele ośrodków: m.in.: hospicjum dla chorych i umierających w Chilandze, które objęła w 1996 r. swoim patronatem; szpitale w Zambii, Tanzanii, Papua-Nowej Gwinei, Indiach i Ugandzie. Największą pomoc przekazano na budowę i wyposażenie przychodni w Kiabakari. W latach 2003-2010 Fundacja wysłała 1180 paczek. Pomoc trafiła do Ameryki Środkowej (Jamajka), Afryki, Azji, Oceanii oraz niektórych państw europejskich (Białoruś, Ukraina). W kartonach obszytych płótnem nadawane są materiały opatrunkowe, leki, odzież (szczególnie do Afganistanu), a także przybory szkolne i mleko w proszku. Fundacja zabiega o darowizny z firm farmaceutycznych, a koszty transportu paczek stara się obniżać przy współpracy z polskimi żołnierzami biorącymi udział w misjach stabilizacyjnych. Nie bez znaczenia jest również otrzymywane przez nią wsparcie od instytucji zrzeszonych w Medicus Mundi International. Wszystkie te działania zwiększają jej możliwości, a dotychczasowe wysiłki czynią jeszcze bardziej efektywnymi.

\section{Centrum zdrowia w Kiabakari}

Kiabakari to tanzańska wioska na północy kraju w rejonie Mara. To właśnie tam Fundacja we współpracy z Ministerstwem Spraw Zagranicznych Rzeczpospolitej Polskiej i wsparciem Salezjańskiego Wolontariatu Misyjnego wybudowała ośrodek zdrowia: Blessed Pier Georgio Frassati Health Center.

Zła sytuacja zdrowotna 70 tys. mieszkańców regionu i brak dostępu do podstawowej opieki medycznej, coraz większa śmiertelność i budzące grozę praktyki miejscowych szamanów to obrazy, które przekonały tysiące ludzi i instytucji do wsparcia tejże inicjatywy ${ }^{7}$. Budowa Centrum była trudna i trwała około 8 lat. Ośrodek przyjmuje pacjentów od 18 stycznia 2008 r. Jest jednym z najlepiej wyposażonych dyspanserów działających na kontynencie afrykańskim. Zespół medyczny dwa razy w miesiącu udaje się na tzw. klinikę wyjazdową, by dotrzeć do tych, którzy zamieszkują tereny w znacznej odległości od wioski Kiabakari. Przychodnia prowadzi program szczepień i stara się wdrażać programy promocji zdrowia na terenie tanzańskich wiosek. Wolontariusze Fundacji administrowali ośrodkiem przez blisko dwa lata, po czym funkcję tę przejęły Siostry Służebniczki Starowiejskie. Nadal jest on miejscem praktyk studenckich i wypraw mających na celu udzielanie specjalistycznej pomocy medycznej.

\section{Akcje}

Wysiłki misjonarzy Fundacja stara się wspierać poprzez różnorodne akcje organizowane na terenie kraju. Oprócz pomocy mają one jeszcze inny wymiar -

\footnotetext{
${ }^{7}$ Por. N. Rehlis, Budujemy przychodnię, "Raport" 2 (1999) nr 2, s. 1-2.
} 
aktywizują środowiska i uwrażliwiają na potrzeby misji tych, do których są W stanie dotrzeć.

W 2010 r. zorganizowano akcję pod tytułem Ołówek dla Afryki. Pod natchnieniem fragmentu $\mathrm{Hebanu}^{8}$ Ryszarda Kapuścińskiego rozpoczęto zbieranie przyborów szkolnych. Dlaczego ołówek stał się symbolem pomocy dla afrykańskiej społeczności młodych ludzi? Bo to właśnie jego cena przesądza o tym, że dziecko nie jest posyłane do szkoły. Edukacja to jedyna szansa na poprawę sytuacji na Czarnym Lądzie. Koszt przyborów szkolnych i nauki decyduje nie tylko o przyszłości dziecka, ale całej jego rodziny, społeczeństwa, które nadal uważa to za zbędny wydatek. Dziecko, które nie idzie do szkoły nigdy nie nauczy się języka urzędowego, nie nauczy się pisać ani czytać i w rezultacie nie podejmie pracy zarobkowej. Samo nie pokona bariery językowej. Nie będzie miało szansy wyjścia z biedy czy nędzy, nie dowie się jak dbać o swoje zdrowie i zapobiegać chorobom, które dziesiątkują społeczność afrykańską.

Do akcji włączyły się setki instytucji: szkoły, przedszkola, uczelnie, przedsiębiorstwa. W efekcie udało się zgromadzić cztery tony przyborów szkolnych, a także darowizny pieniężne, które przeznaczone zostały na wysyłkę paczek do Afryki.

Redemptoris Missio od 2009 r. angażuje się w akcję adopcyjną. Beneficjentami pomocy jest afrykańska młodzież szkolna i studenci z obszaru Kamerunu. Fundacja szuka rodziców adopcyjnych wśród Polaków po to, by stworzyć dla zdolnej młodzieży warunki do zdobywania wykształcenia. Jej zadaniem jest pośrednictwo w adopcji na odległość, czyli przekazywanie środków od rodziców adopcyjnych, informowanie o kosztach zdobywania wykształcenia, postępach w nauce i sytuacji rodzinnej podopiecznego ${ }^{9}$. Organizuje także kilka razy w roku spotkania dla rodziców biorących udział w projekcie.

Daj im szansę to trzeci projekt związany z edukacją młodzieży w krajach misyjnych. Ideę wzniecił Adam Bobkiewicz, lekarz medycyny, który w 2009 r. odwiedził Ugandę. Poruszony historią pięciorga wspaniałych Ugandczyków przywiózł do Polski rysunki nastoletniego chłopca, które jako cegiełki są sprzedawane w celu pozyskania finansów na edukację. Do końca 2010 r. udało się zebrać na ten cel około 4 tys. zł.

Los niewinnego społeczeństwa udręczonego biedą i brakiem pokoju w Afganistanie przyczynił się do organizacji akcji: Pomoc dla Afganistanu. Dla bosych

\footnotetext{
${ }^{8} \mathrm{Na}$ plakacie promocyjnym akcji umieszczony został następujący cytat: (...) Głód wśród tych dzieci jest czymś stalym, jest forma życia, drugq naturq. A jednak to, o co prosza, nie jest prośbq o chleb czy owoc, nie jest nawet prośbq o pieniqdze. Proszq o ołówek. Ołówek kulkowy, cena dziesięć centów. Tak, ale skąd wziqć dziesięć centów? A oni wszyscy chcieliby chodzić do szkoły, chcieliby się uczyć. R. Kapuściński, Heban, Warszawa 1999, s. 243.

${ }^{9}$ Por. Adopcja na odległość, "Raport" 2 (2009) nr 44, s. 3.
} 
i zmarzniętych dzieci Fundacja zorganizowała zbiórkę ciepłej odzieży. Kilkumiesięczna akcja trwająca od stycznia do marca 2010 r. powtórzona została w styczniu i w lutym 2011 r. pod hasłem Afganistan II. Zbiórka odzieży jak i darowizn pieniężnych zakończyła się w marcu 2011 r. Dary gromadzone były w centrum wolontariatu przy ul. Grunwaldzkiej, skąd posegregowane i spakowane trafiły do wojskowych samolotów. Transport z lutego 2011 r. do Afganistanu składał się z 7 tysięcy $^{10}$, a z czerwca 2010 r., z 12 tysięcy sztuk ciepłych rzeczy ${ }^{11}$. Żołnierze stacjonujący w Afganistanie własnoręcznie rozdzielali ciepłą odzież wśród potrzebujących.

Dla ratowania życia i zdrowia najmniejszych i bezbronnych Fundacja zainicjowała akcję Puszka dla Maluszka, polegającą na zbieraniu aluminiowych puszek. W krajach rozwijających się umieralność dzieci jest niewyobrażalnie wysoka - tylko w Tanzanii umiera co siódme dziecko przed ukończeniem piątego roku życia ${ }^{12}$. Pierwsza akcja odbyła się w 2009 r. pod hasłem: Razem podarujmy zycie wielu dzieciom. Dochód $\mathrm{z}$ akcji pozwolił na zakup trzech inkubatorów oraz przekazanie 5 tys. zł. na zakup leków dla kameruńskich dzieci ${ }^{13}$. Druga edycja Puszki dla maluszka odbyła się w 2010 roku $^{14}$. Do Demokratycznej Republiki Konga przekazano, dzięki darowiznom polskich firm farmaceutycznych, leki o wartości 40 tys. zł, oraz zebrano 2,5 tony aluminiowych puszek. Akcję zorganizowano także w $2011 \mathrm{r}$.

W 2008 r. Fundacja przystąpiła do realizacji afrykańsko-europejskiego projektu Stop Malaria Now!, który zainicjowany został przez Medicus Mundi International. Kampania ma na celu uświadomienie rządów i jak największej liczby ludności o skutkach malarii. O samej chorobie mieszkańcy kontynentu europejskiego wiedzą niewiele. Dotyczy to także personelu medycznego. Ożywiony ruch turystyczny w rejony endemiczne powoduje, iż rocznie do Polski zawleczonych zostaje kilka przypadków zimnicy. Niestety aż co dziesiąty chory umiera' ${ }^{15}$. W Afryce i innych obszarach malarycznych zbiera ona co roku olbrzymie żniwo. WHO szacuje, że co pół minuty zabija ona jedno dziecko, a rocznie jest odpowiedzialna za 3 miliony zgonów. Choroba ta hamuje wzrost gospodarczy w krajach rozwijających się i potęguje biedę. Nie da się jej całkowicie wyeliminować, ale dzięki wspólnym staraniom można ją kontrolować ${ }^{16}$. Fundacja zdecy-

\footnotetext{
${ }^{10}$ Por. Relacja z przebiegu akcji - Pomoc dla Afganistanu, http://www.medicus.amp.edu.pl/ index.php/podsumowania-akcji-puszka-dla-maluszka/pomoc-dla-afganistanu/zakoczenie-akcji.html, strona aktywna 7.04.2011 r.

${ }^{11}$ Por. Dar dla Afganistanu, "Raport" 2 (2010) nr 47, s. 3.

${ }^{12}$ Por. M. Cofta, postTANZANIUM, "Raport" 1 (2010) nr 46, s. 2.

${ }^{13}$ Por. Trzy inkubatory z akcji "Puszka dla Maluszka" sq już w Kamerunie, "Raport" 1 (2010) nr 46, s. 4.

${ }^{14}$ Por. J. Janiec-Palczewska, Akcja „Puszka dla Maluszka”, "Raport” 3 (2010) nr 48, s. 1.

${ }^{15}$ Por. Stop Malaria Now!, MMP 9 (2009) nr 28/29, s. 9.

${ }^{16}$ Por. Stop Malaria Now!, "Raport" 3 (2008) nr 40, s. 1-2.
} 
dowała się poprzeć tę inicjatywę. Oprócz rozprowadzania ulotek, artykułów w Medicus Mundi Polonia czy Raporcie organizowała koncerty ${ }^{17}$ i akcje. 28 września 2008 r., we współpracy z Kliniką Chorób Tropikalnych i Pasożytniczych zorganizowano w gmachu Uniwersytetu Medycznego konferencję: Zwalczanie malarii w kraju i na misjach ${ }^{18}$. Fundacja popularyzowała także akcję: Pokaż swoja swarz przeciwko malarii, której kulminacyjnym punktem było wystosowanie szczególnej petycji do władz Unii Europejskiej. Wolontariusze Redemptoris Missio: Agnieszka Łuczak i Bartosz Dubrowski zorganizowali 21 listopada 2008 r. koncert charytatywny: Szczecinek dla Afryki. Był on uwieńczeniem trwających od 5 dni imprez kulturalnych. Podczas jego trwania uczniowie Liceum w Szczecinku zapoznali się z akcją Stop Malaria Now! Odbyła się aukcja, na której zlicytowano pamiątki przywiezione przez wolontariuszy z Afryki oraz grafiki i obrazy poznańskich artystów. Za pieniądze pozyskane w trakcie koncertu zakupione zostały leki i moskitiery dla trzech krajów afrykańskich ${ }^{19}$. W 2009 r. zorganizowano w Poznaniu Tydzień Malarii. W 2010 r. ruszyła druga edycja tego przedsięwzięcia. Poznań gościł 28 stycznia 2010 r. koordynatorów projektu z 6 organizacji europejskich. Dla krajów borykających się z problemem malarii, komitet Stop Malaria Now! opracował przewodnik, wyjaśniający jak mogą ubiegać się o udzielenie pomocy z Funduszu Światowego. Rozpisano także konkurs na krótki film o zimnicy ${ }^{20}$.

Fundacja włączając się w międzynarodową inicjatywę, na różne sposoby stara się zainteresować polskie społeczeństwo problemem malarii i uświadomić, że stanowi on, mimo wciąż egzotycznego wydźwięku, także problemem zdrowia publicznego w naszym kraju.

\section{PROPAGOWANIE WIEDZY O MISJACH I MISJONARZACH ORAZ DZIAŁALNOŚĆ WYDAWNICZA}

\section{Realizacja filmów}

Jednym z zapisanych w Statucie Fundacji zadań, jest realizacja filmów o tematyce misyjnej. Już od początku swojego powstania starała się, mimo ograniczonych środków, wspierać produkcję krótkometrażowych filmów, promujących działalność misjonarzy w odległych, ubogich krajach. W pierwszym roku dzia-

${ }^{17}$ Zob. Koncert pod hastem "Stop Malaria Now!, "Raport" 1 (2009) nr 43, s. 3.

${ }^{18}$ Zob. J. Polowy, Stop Malaria Now!, MMP 8 (2008) nr 26/27, s. 7, 13.

${ }^{19}$ Zob. "Szczecinek dla Afryki" Koncert charytatywny Fundacji Pomocy Humanitarnej Redemptoris Missio, "Raport" 5 (2008) nr 42, s. 3-4 lub: B. Dąbrowski, "Szczecinek dla Afryki" Koncert charytatywny Fundacji Pomocy Humanitarnej Redemptoris Missio, MMP 8 (2008) nr 26/ 27, s. 8-9.

${ }^{20}$ Por. J. Polowy, Projekt “Stop Malaria Now!”, MMP 10 (2010) nr 32/33, s. 7-8. 
łalności Fundacji, w grudniu, fundatorzy: ks. Ambroży Andrzejak i lek. med. Norbert Rehlis zaangażowali się w realizację filmu pt. W sercu Afryki, o polskiej misjonarce, lek. med. Wandzie Błeńskiej ${ }^{21}$. Krótka, półgodzinna produkcja, prezentuje sylwetkę Matki trędowatych, która ponad czterdzieści lat spędziła w Afryce. Wraz z jej przyjazdem spełniły się marzenia wielu. Podjęcie pracy przez młodą lekarkę w ugandyjskim leprozorium, odnotowano w kronice pod znakiem ogromnej radości, radości z długo wyczekiwanego gościa. Buluba stała się jej domem. Dokta natomiast, najbardziej znaną wśród Ugandyjczyków lekarką. Film zrealizowany został przez Ryszarda Piaska i Zespół Filmowy Videonik. Był emitowany w telewizji, a także podczas spotkań w Centrum Wolontariatu Fundacji.

Kolejny film, Kalkuta - miasto Matki Teresy powstał w 1993 r., podczas drugiej wyprawy medycznej zorganizowanej przez Fundację, do Indii. Film wyemitowano w telewizji dnia 28 maja 1993 r., przy okazji przyjazdu Matki Teresy z Kalkuty do Polski ${ }^{22}$. W telegraficznym skrócie opowiada on o życiu znanej na całym świecie Misjonarki Miłości. Ukazuje jej miłosierne serce, jakim od lat dzieli się z mieszkańcami indyjskich slumsów. Siłę do tej ciężkiej pracy czerpie z modlitwy i codziennej adoracji Najświętszego Sakramentu. Matka Teresa to ta, która walczy o godność umierającego, chorego, sponiewieranego. Wspólnie z siostrami stara się zapewnić ludzkie warunki tym, którzy odchodzą z tego świata. Przez ten właśnie pryzmat film pokazuje ulice tytułowej Kalkuty.

Kilkunastominutowy film Misyjne kliniki w Papua-Nowej Gwinei powstał w 2002 r. Norbert Rehlis, realizator i producent, pokazuje jak polski personel medyczny niesie pomoc ludziom, na największej wyspie Oceanu Spokojnego. W kraju targanym międzyplemiennymi walkami działają polscy misjonarze. Brak dróg, kataklizmy i niełatwa sytuacja społeczno - polityczna i ekonomiczna kraju utrudnia udzielanie pomocy. Na Papua - Nowej Gwinei pracują m.in. ks. Janusz Skotniczny, s. Dorota Piechota i s. Kinga Czerwonka. To właśnie oni prezentują sytuację zdrowotną na wyspie. Mimo, iż w buszu działa ok. 100 misyjnych szpitali i przychodni odczuwają one dotkliwy brak lekarstw i personelu medycznego. Są uzależnione od zagranicznych dostaw farmaceutyków i środków opatrunkowych, gdyż na Papua-Nowej Gwinei nie działa żadna firma produkująca leki. Udzielanie pomocy medycznej komplikuje trudny klimat, brak utwardzonych dróg, a także bogactwo szczepów i języków i kultur, których wg szacunków jest ponad 700. Opieka medyczna na Papua-Nowej Gwinei nie istniałaby bez wsparcia państw Zachodu, do których należy także Polska. Misjonarze apelują o pomoc materialną, ale także o świeckich lekarzy, którzy gotowi są nieść kwalifikowaną pomoc medyczną na Rajskiej Wyspie.

${ }^{21}$ Por. Z. Pawłowski, Fundacja pomocy humanitarnej Redemptoris Missio (Medicus Mundi Poland) 1992-2004 Kalendarium działalności, AMis 14 (2004), s. 201.

${ }^{22}$ Por. tamże. 
W sierpniu 2002 r. przedstawiciele Fundacji pomagali w realizowanym przez Ryszarda Piaska i firmę Videonik filmie o ojcu Marianie Żelazku. Autorem komentarza do tej półgodzinnej produkcji był ks. Ambroży Andrzejak z Redemptoris Missio. Fundacja wspólnie z Komisją Episkopatu ds. Misji objęła swoim patronatem to niezwykłe przedsięwzięcie. Myślą przewodnią filmu Misjonarz jest słynne zdanie o. Mariana: Nie jest trudno być dobrym - wystarczy tylko chcieć! Krótkie sceny ze świętego miasta hinduizmu, Puri, ukazują dzieło życia polskiego werbisty i kandydata do Pokojowej Nagrody Nobla. Po trudnych kolejach życia, pobycie w obozie koncentracyjnym, zdecydował się on poświęcić całkowicie drugiemu człowiekowi. To z jego inicjatywy i starań w mieście, które jest Mekką dla wyznawców hinduizmu, wybudowany został kościół. Otworzył kuchnię miłosierdzia, szkołę dla dzieci noszących ślad tej strasznej choroby, a także szpital i utworzył miejsca pracy. Trędowaci odzyskali dzięki jego wysiłkom swoją godność. Przędą nici, produkują cegłę, robią sznury i powrozy, czy też posługują w kuchni. Potrzeby ośrodka są ogromne $\mathrm{z}$ uwagi na fakt, iż wizja poprawy losu przyciagga do wioski trędowatych coraz większe rzesze dotkniętych chorobą ludzi. Sponsorem tego krótkometrażowego filmu była Polfa Warszawa i Metpol.

\section{Koncert oraz medal Tym, którzy czyniq dobro...}

Chęć osobistego kontaktu z sympatykami i przyjaciółmi Fundacji Pomocy Humanitarnej Redemptoris Missio skłoniła po dwóch latach działalności Radę i Zarząd, do organizowania raz do roku wspólnego spotkania. Zdecydowano, że będzie to uroczyste wydarzenie muzyczne, jak i okazja do propagowania wiedzy o misjonarzach i placówkach misyjnych objętych patronatem Fundacji.

W latach 1994-2010 zorganizowano 15 koncertów ${ }^{23}$. Wszystkie odbyły się w Auli Uniwersytetu im. Adama Mickiewicza w Poznaniu. Dochód ze zbiórek prowadzonych w przerwach koncertu przeznaczony został na cele charytatywne, związane z działalnością Fundacji Pomocy Humanitarnej Redemptoris Missio. Dziesięciokrotnie koncert uświetnił występ Chóru Chłopięcego i Męskiego Filharmonii Narodowej Poznańskie Stowiki, trzykrotnie wieczór należał do Orkiestry Reprezentacyjnej Sił Powietrznych, a ostatnie dwa koncerty wspólnie z orkiestrą mjr Pawła Joksa poprowadził Chór Uniwersytetu Medycznego. Podczas tychże spotkań wręczono 18 medali Tym, którzy czyniq dobro..., w tym jeden nadano pośmiertnie (Zofii Florczak). Koncert szybko stał się jednym z najważniejszych przedsięwzięć Fundacji. Jest on okazją do wyrażenia podziękowania sympatykom, darczyńcom, wolontariuszom za ich całoroczne zaangażowanie, buduje więź i propagując wiedzę o misjach uwrażliwia na złą sytuację zdrowotną w krajach rozwijających się.

\footnotetext{
${ }^{23}$ Wybrane szczegóły przedstawia tabela nr 2.
} 
Tab. 2. Koncerty zorganizowane przez Fundację Pomocy Humanitarnej Redemptoris Missio w latach 1994-2010.

\begin{tabular}{|c|c|c|c|c|}
\hline Lp. & Data & $\begin{array}{c}\text { Odznaczeni } \\
\text { medalem }\end{array}$ & Uwagi & $\begin{array}{c}\text { Oprawa } \\
\text { muzyczna }\end{array}$ \\
\hline 1. & 04.10 .1994 & - & $\begin{array}{l}\text { 60-lecie działalności } \\
\text { dr Wandy Błeńskiej }\end{array}$ & $\begin{array}{l}\text { Poznańskie } \\
\text { Stowiki }\end{array}$ \\
\hline 2. & 11.10 .1995 & - & $\begin{array}{l}\text { poświęcony pamięci } \\
\text { o. Jana Beyzyma }\end{array}$ & $\begin{array}{l}\text { Poznańskie } \\
\text { Stowiki }\end{array}$ \\
\hline 3. & 22.12 .1996 & $\begin{array}{l}\text { prof. Stefan } \\
\text { Stuligrosz } \\
\text { Zofia Florczak } \\
\end{array}$ & & $\begin{array}{l}\text { Poznańskie } \\
\text { Stowiki }\end{array}$ \\
\hline 4. & 22.06 .1998 & o. Marian Żelazek & $\begin{array}{l}\text { 50-lecie kapłaństwa i } 80 \text { ur. } \\
\text { o. M. Żelazka }\end{array}$ & $\begin{array}{l}\text { Poznańskie } \\
\text { Stowiki }\end{array}$ \\
\hline 5. & 23.03 .1999 & $\begin{array}{l}\text { ks. Wojciech } \\
\text { Łazewski }\end{array}$ & $\begin{array}{l}15 \text { rocznica śmierci } \\
\text { o. Czesława Białka }\end{array}$ & $\begin{array}{l}\text { Poznańskie } \\
\text { Stowiki }\end{array}$ \\
\hline 6. & 30.06 .2000 & $\begin{array}{l}\text { dr Edgar Wider } \\
\text { prof. Miquel } \\
\text { Argali } \\
\text { dr Sake Rypkema }\end{array}$ & $\begin{array}{l}\text { Zjazd Zarządu Medicus Mundi } \\
\text { International w Poznaniu }\end{array}$ & $\begin{array}{l}\text { Poznańskie } \\
\text { Stowiki }\end{array}$ \\
\hline 7. & 08.11 .2001 & dr Wanda Błeńska & 90 ur. dr Wandy Błeńskiej & $\begin{array}{l}\text { Poznańskie } \\
\text { Stowiki }\end{array}$ \\
\hline 8. & 17.10 .2002 & $\begin{array}{l}\text { Prof. Michał } \\
\text { Drews } \\
\text { ks. Aleksy } \\
\text { Stodolny } \\
\end{array}$ & 10-lecie FPH Redemptoris Missio & $\begin{array}{l}\text { Poznańskie } \\
\text { Stowiki }\end{array}$ \\
\hline 9. & 08.02 .2004 & $\begin{array}{l}\text { Siostry } \\
\text { Misjonarki } \\
\text { Miłości }\end{array}$ & $\begin{array}{l}\text { poświęcony pamięci bł. Matki } \\
\text { Teresy z Kalkuty }\end{array}$ & $\begin{array}{l}\text { Poznańskie } \\
\text { Stowiki }\end{array}$ \\
\hline 10. & 27.01 .2005 & $\begin{array}{l}\text { Instytut Misyjny } \\
\text { Laikatu im. Dr } \\
\text { Wandy Błeńskiej }\end{array}$ & & $\begin{array}{l}\text { Poznańskie } \\
\text { Stowiki }\end{array}$ \\
\hline 11. & 27.02 .2006 & dr Helena Pyz & & $\begin{array}{l}\text { Orkiestra } \\
\text { Reprezentacyjna } \\
\text { Sił Powietrznych } \\
\end{array}$ \\
\hline 12. & 13.02 .2007 & $\begin{array}{l}\text { Flying Medical } \\
\text { Services }\end{array}$ & $\begin{array}{l}\text { poświęcony pamięci: o. M. Żelazka, } \\
\text { ks. A. Stodolnego, K. Feldman }\end{array}$ & $\begin{array}{l}\text { Orkiestra } \\
\text { Reprezentacyjna } \\
\text { Sił Powietrznych } \\
\end{array}$ \\
\hline 13. & 01.04 .2008 & $\begin{array}{l}\text { ks. Wojciech } \\
\text { Kościelniak } \\
\text { lek. med. Gabriela } \\
\text { Majkut }\end{array}$ & & $\begin{array}{l}\text { Orkiestra } \\
\text { Reprezentacyjna } \\
\text { Sił Powietrznych }\end{array}$ \\
\hline 14. & 07.03 .2009 & $\begin{array}{l}\text { s. Józefina } \\
\text { Grabowska }\end{array}$ & $\begin{array}{l}\text { Hasło: Stop Malaria Now! } \\
\text { Wręczenie dr W. Błeńskiej } \\
\text { Dyplomu Honorowego Członka } \\
\text { Rady Fundacji }\end{array}$ & $\begin{array}{l}\text { Orkiestra } \\
\text { Reprezentacyjna } \\
\text { Sił Powietrznych; } \\
\text { Chór Uniwersytetu } \\
\text { Medycznego }\end{array}$ \\
\hline 15. & 13.03 .2010 & $\begin{array}{l}\text { mjr Paweł Joks } \\
\text { (Orkiestra } \\
\text { Reprezentacyjna } \\
\text { Sił Powietrznych) }\end{array}$ & & $\begin{array}{l}\text { Orkiestra } \\
\text { Reprezentacyjna } \\
\text { Sił Powietrznych; } \\
\text { Chór Uniwersytetu } \\
\text { Medycznego }\end{array}$ \\
\hline
\end{tabular}




\section{Działalność wydawnicza}

Raport, czyli Biuletyn Informacyjny Członków i Sympatyków Fundacji Pomocy Humanitarnej "Redemptoris Missio" wydawany jest od października 1994 r. Okazją i niejako sposobnym czasem do wydania pierwszego numeru stało się nadanie Wandzie Błeńskiej, przez Akademię Medyczną w Poznaniu tytułu doctora honoris causa ${ }^{24}$. Jak pisze we wstępie pierwszy redaktor tego folderu, prezes Fundacji Norbert Rehlis, Raport powstał dla celów informacyjnych oraz integracyjnych.

Wszystkie numery, a w latach 1994-2010 wydano ich 48, opatrzone zostały w nagłówku przesłaniem Matki Teresy z Kalkuty: Nikt z nas nie żyje tylko dla siebie... . Cztero stronnicowy biuletyn zawiera krótkie informacje o bieżącej działalności Fundacji, prezentuje sylwetki misjonarzy: o. Jana Beyzyma ${ }^{25}$, Matki Teresy z Kalkuty ${ }^{26}$, dr Wandy Błeńskiej ${ }^{27}$, o. Mariana Żelazka ${ }^{28}$, o. Czesława Bia$\mathrm{ka}^{29}$. Ten bezpłatny informator przekazywany jest sympatykom i wolontariuszom Fundacji średnio 2-3 razy w roku ${ }^{30}$. Nie posiada on stałych rubryk, ale w każdym numerze redaktor zwraca się bezpośrednio do czytelnika, w celu wprowadzenia w poruszaną tematykę, czy też po to, by podziękować, przekazać życzenia lub też przybliżyć nowe cele i plany Fundacji. Pismo jest dobrym źródłem informacji o zmianach personalnych w Radzie i Zarządzie Fundacji, organizowanych koncertach, czy też spotkaniach i kursach. To na jego łamach możemy przeczytać o organizowanych akcjach i ich wynikach, przedsięwzięciach, takich jak otwarcie ośrodka w Kiabakari ${ }^{31}$, oraz wszelkich ważnych dla Fundacji wydarzeniach (w tym jubileuszach). Redakcja zamieszcza treści listów misjonarzy, w których zwykle dziękują za otrzymaną pomoc medyczną, lub nakreślając warunki i potrzeby krajów misyjnych, dopiero zwracają się z prośbą o nią. Raport jest bogato opatrzony zdjęciami, co odróżnia go od kwartalnika Medicus Mundi Polonia. W ciagu siedemnastu lat Raport miał czterech redaktorów ${ }^{32}$.

${ }^{24}$ Zob. A. Józefczyk, Dr Błeńska - "Matka Trędowatych", "Raport" 1 (1994) nr 1, s. 1-2.

${ }^{25}$ Zob. A. Walkowiak, Ojciec Jan Beyzym, "Raport" 4 (1995) nr 2, s. 1-2.

${ }^{26}$ Zob. N. Rehlis, $W$ stużbie miłości..., "Raport" 8 (1997) nr 2, s. 1-2.

${ }^{27}$ Zob. A. Józefczyk, Jubileusz, "Raport" 6 (1996) nr 2, s. 1-2; M. Zaradniak, 90. rodziny Dr h.c. Wandy Bteńskiej, "Raport" 18 (2001) nr 1, s. 1-2.

${ }^{28}$ Zob. A. Walkowiak, N. Rehlis, Stuga trędowatych, "Raport" 1 (1998) nr 9, s. 1-2; N. Rehlis, S. Ast, Dziękuję Wam Przyjaciele..., "Raport" 15 (2001) nr 1, s. 1-3; Ojciec Marian Żelazek $w$ Polsce, "Raport" 21 (2002) nr 3, s. 4; A. Kaniewska, Z pomoca u Ojca Mariana w Puri, "Raport" 27 (2004) nr 3, s. 3.

${ }^{29}$ Zob. M. Drozdowicz, Tym, którzy czyniq dobro..., "Raport" 11 (1999) nr 1, s. 1-2.

${ }^{30} \mathrm{~W}$ latach 2001, 2005 i 2006 wydane zostały 4 numery Raportu; natomiast w 2008 r. było ich 5.

${ }^{31}$ Por. M. Cofta, Centrum zdrowia w Kiabakari, "Raport" 39 (2008) nr 2, s. 1-4.

${ }^{32}$ Pierwsze 27 numerów zredagował Norbert Rehlis, a wydrukowała firma Druk-Intro Inowrocław. Głównym redaktorem numerów 28 - 44 był Mateusz Cofta. Zmianie uległo także miejsce 
Mimo, iż strona internetowa prężnie działa już od 2003 r., a sympatycy coraz chętniej szukają informacji w sieci, Raport nadal spełnia ważną rolę pierwszego informatora. Na ręce przyjaciół Fundacji trafia listownie, a swoim zasięgiem obejmuje całą Polskę. Patrząc z perspektywy kilkunastu lat wydaje się, że spełnia on postawione przed sobą zadania integracji środowiska skupionego wokół zaplecza medycznego dla polskich misji oraz przekazu ważnych informacji.

Kwartalnik Medicus Mundi Polonia wydawany jest przez Fundację od lutego 2001 r. Tytuł w sposób jednoznaczny podkreśla fakt zrzeszenia Fundacji Pomocy Humanitarnej Redemptoris Missio w międzynarodowej organizacji Medicus Mundi International, natomiast podtytuł tego czasopisma: Przeznaczony dla osób zainteresowanych problemami medycznymi wchodzacymi w zakres tzw. medycyny tropikalnej $i$ "International Heath" ze szczególnym uwzględnieniem potrzeb misyjnych ośrodków medycznych ${ }^{33}$, określa odbiorce.

Po prawie siedmiu latach wydawania Raportu Rada i Zarząd Fundacji dostrzegły potrzebę przygotowania polskiego czasopisma poświęconego problemom zdrowotnym krajów trzeciego świata. Redakcja ${ }^{34}$ postawiła przed Medicus Mundi Polonia cztery zadania. Ma on przekazywać ważne informacje z zakresu zdrowia publicznego, a w sposób szczególny dotyczące epidemiologii chorób tropikalnych i pasożytniczych. Na kanwie tychże informacji, poruszane mają być problemy, $\mathrm{z}$ jakimi borykają się osoby pracujące $\mathrm{w}$ misyjnych szpitalach i ośrodkach opieki ambulatoryjnej. Podobnie jak Raport, powinien być on środkiem integracji części polskiego społeczeństwa, która poczuwa się do odpowiedzialności za posłanych, do najbiedniejszych krajów świata misjonarzy. Drugim zaś wspólnym celem tychże pozycji jest chęć, a wręcz potrzeba dotarcia, do jak największej rzeszy wrażliwych na problemy misji ludzi. Wszystko zaś po to, by poprzez zorganizowane działania wspierać rodzimych misjonarzy, budując fachowe zaplecze medyczne.

Struktura Medicus Mundi Polonia jest przemyślana i uwzględnia powyższe wymagania. Mimo kilku modyfikacji cechuje ją przejrzystość. Każdy numer kwartalnika na swoich kilkunastu stronach skupia się wokół aktualności w środowisku Fundacji, Medicus Mundi International oraz Światowej Organizacji Zdrowia. Znajdziemy tam również omówienie chorób czy problemów dotykających ludność w krajach rozwijających się. Jest doskonałym informatorem o prowadzonych szkoleniach z zakresu medycyny tropikalnej odbywających się na całym świecie. Prezentuje i poleca fachową literaturę, informuje o ukazaniu się

druku, na M-Druk Wagrowiec. Raport numer 46, 47 i 48 zredagowała Anna Kurkowiak, a 48 Agnieszka Lipińska.

${ }^{33}$ MMP 1 (2001) nr 1, s. 1.

${ }^{34}$ Redaktorem MMP jest Z. Pawłowski, sekretarzy redakcji było 4. Nr 1-11 MMP - N. Rehlis. Od nr 12/13-19/20 rolę sekretarza redakcji wypełniał A. Waśniowski. Następnie zastąpiła go K. Mrówka - nr 21-22/23. E. Kaczmarek była sekretarzem redakcji nr 26/27-34/35. W nr 28/29 została wprowadzona funkcja z-cy redaktora i pełniła ją A. Magowska (do końca 2010 r). 
nowych pozycji, wskazuje na źródła informacji, szczególnie strony internetowe. Stałą i odporną na zmiany jest rubryka Postuga Lecznicza Kościoła, która redagowana jest przez prof. Zbigniewa Pawłowskiego.

Nakład 1000 egzemplarzy (liczba ta wahała się od 800-1500) trafia do zakonów i placówek misyjnych, bibliotek wydziałowych uczelni medycznych, Centrum Formacji Misyjnej, oraz sympatyków i wolontariuszy Fundacji. Pierwszy egzemplarz kwartalnika otrzymał także papież Jan Paweł II. Rzetelność i funkcjonalność kwartalnika podkreśla fakt, iż po czterech latach jego wydawania, w numerze piętnastym redakcja zamieszcza aneks autorów i tematów opublikowanych w Medicus Mundi Polonia w numerach 1-1435. Kolejne tego typu zestawienie znajdziemy w numerze dwudziestym pierwszym, a obejmuje ono numery, które ukazały się do końca roku $2006^{36}$.

Wraz z wydaniem szóstego numeru, który jest pierwszym numerem podwójnym redakcja zapoczątkowuje formę podwójnego egzemplarza ${ }^{37}$. Nowa forma powoduje, że kwartalnik ukazuje się rzadziej, ale jest to zabieg mający na celu zmniejszenie ciężaru finansowego związanego z publikacją i wysyłką czasopisma. Należy tu podkreślić, że podobnie jak Raport, kwartalnik Medicus Mundi Polonia jest wydawany i rozprowadzany bezpłatnie. Czytelników skłania się tylko do partycypowania na miarę możliwości w kosztach jego powstawania. Nie określa się jednak żadnej konkretnej kwoty.

O przełomowych zmianach wymuszanych dostosowaniem się do rozwoju techniki i powszechności informatyzacji, informuje czytelników redakcja kwartalnika w numerze 19/20. W związku ze wspomnianym postępem technicznym redakcja miała odtąd podawać przydatne i ciekawe adresy internetowe, a Medicus Mundi Polonia miał być dostępny w formie elektronicznej - na dyskach optycznych i stronie Fundacji ${ }^{38}$. Kolejne reformy dotyczące formy publikacji są zamieszczone w numerze 28/29. Wspólnie z Wydawnictwem Kontekst podjęto zobowiązanie publikacji kwartalnika $\mathrm{w}$ formie papierowej dwukrotnie $\mathrm{w}$ ciagu roku, natomiast czterokrotnie w wersji elektronicznej, która zostanie udostępniona na stronie internetowej Fundacji. Do końca 2010 r. ukazało się 35 numerów Medicus Mundi Polonia. Ilość wydanych numerów ukazuje wykres poniżej, na którym dla porównania zamieszczone zostały dane dotyczące Raportu.

${ }^{35}$ Zob. Spis autorów i tematyka kwartalnika "Medicus Mundi” (2001-2004), MMP 4 (2004) nr 15 , s. 1.

${ }^{36}$ Zob. Spis autorów i tematyka kwartalnika "Medicus Mundi Polonia (zeszyty nr 1-20, lata 2002-2006), MMP 7 (2007) nr 21, s. 20.

${ }^{37}$ Do końca 2010 r. wydanych zostało 11 podwójnych numerów MMP.

${ }^{38} \mathrm{O}$ ile płyty $\mathrm{CD}$ z treścią $M M P$ można z łatwością pozyskać po skontaktowaniu się z Biurem Fundacji, o tyle nie można ich znaleźć na stronie internetowej Fundacji. Część, zaledwie 11 numerów udostępnia na swojej stronie Wydawnictwo Kontekst. Por. Od Redakcji, MMP 6 (2006) nr 19/20, s. 1; zob. Strona wydawnictwa Kontekst, http://www.wkn.h2.pl/wyd/index.php/czasopisma/medic us-mundi-international, strona aktywna 23.03.2011 r. 


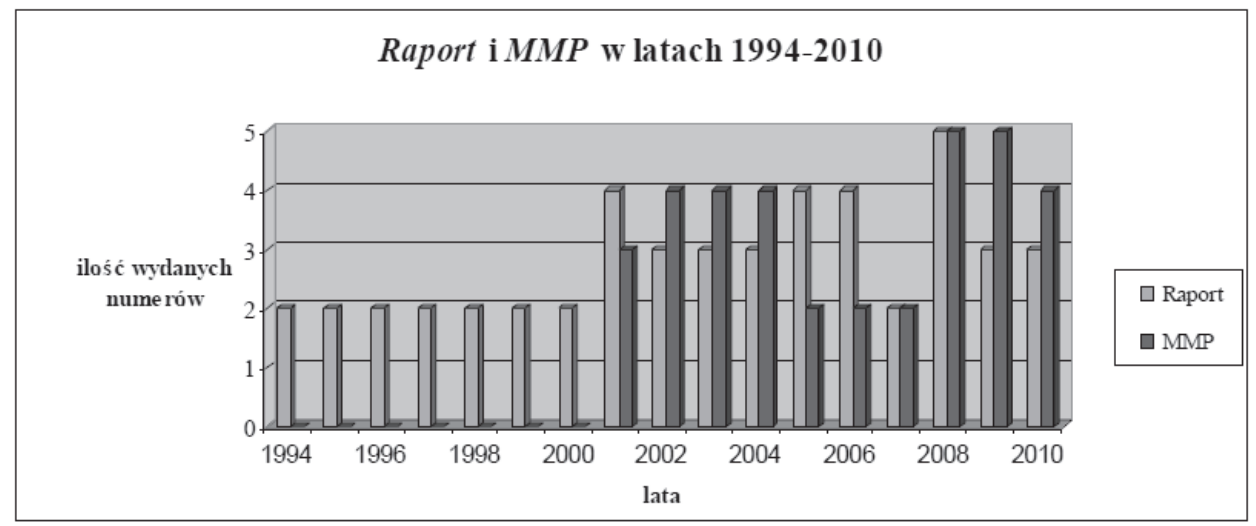

Ryc. 2. Ilość numerów Raportu i Medicus Mundi Polonia wydanych w latach 1994 - 2010.

Annales Misiologici Posnanienses to przedwojenne czasopismo i jego dzieje łączą historię rozwoju misjologii w Polsce z aktualną działalnością na rzecz misji, którą realizuje Fundacja Pomocy Humanitarnej Redemptoris Missio. Rocznik ma bogatą tradycję i sięga do początków ruchu misyjnego w naszym kraju. Jako pierwsze czasopismo poświęcone zagadnieniom misji, ukazał się po raz pierwszy w 1928 r. pod tytułem: Roczniki Zwiazku Akademickich Kół Misyjnych $w$ Polsce. Redaktorem pierwszego numeru był Stefan Abt. Czasopismo nie przypadkowo wydawane było w Poznaniu. Tam bowiem mieścił się Zarząd Akademickich Kół Misyjnych, a po nim Komitet Propagandy Misyjnej wśród Inteligencji przy Papieskim Dziale Rozkrzewiania Wiary. Następne tomy ukazały się kolejno w 1929 r., na przełomie 1930 i 1931 r. Redaktorem trzeciego numeru był Zygmunt Ołyński wraz z Wandą Błeńską, a czwartego (na przełomie 1931 i 1932 r.) i zarazem ostatniego, jaki ukazał się pod tą nazwą - Wanda Błeńska. Wraz z przejęciem funkcji redaktora przez Kazimierza Kapitańczyka, zmieniła się nazwa rocznika na: Annales Missiologicae. Roczniki Misjologiczne. Pod nową nazwą wydane zostały tomy $\mathrm{V}-\mathrm{X}$. Podtytuł podkreśla, że jest to czasopismo roczne poświęcone zagadnieniom misjowiedzy, a nie jak do tej pory misjologii. Zasadniczym redaktorem tychże tomów był Kazimierz Kowalski, przy czym numer szósty z 1934 r. zredagowała Wanda Błeńska.

Okres wojny był czasem strat i zniszczeń, co uwidoczniło się także w rozwoju polskiej myśli misjologicznej. Zaprzestano wydawać rocznik na wiele lat. Dopiero w 2000 r. poznańskie środowisko misjologiczne skupione przy Uniwersytecie im. Adama Mickiewicza w Poznaniu, wsparte pomocą ze strony Fundacji Pomocy Humanitarnej Redemptoris Missio powzięło myśl o wznowieniu wydawania owego rocznika. W ten oto sposób, w roku milenijnym ukazał się jedenasty tom Roczników Misjologicznych Annales Missiologicae Posnanienses, pod redakcją fundatora Redemptoris Missio, ks. Ambrożego Andrzejaka. 
Rocznik zawiera głębokie rozważania z zakresu teologii misji, oparte na dokumentach Magisterium Kościoła, wywiady, elementy religiologii i kulturoznawstwa, a także wiele miejsca poświęca na aktualne wydarzenia na polu działalności misyjnej w różnych ośrodkach misyjnych w kraju i za granicą. Nieodłącznym elementem są informacje o wartościowych dla tematu publikacjach i wydarzeniach z życia Fundacji. Jedenasty tom wydany po 62 latach przerwy, jest swego rodzaju pomostem do współczesnej misjologii. Nie zaciera śladów dziedzictwa poprzednich tomów, na co dowodem jest artykuł Aurelii Szafran-Bartoszek: Bibliografia zawartości "Annales Missiologicae” 1928-193839. Czwarta zmiana tytułu nastapiła ze względów poprawności gramatycznej. W 2003 r. wydano trzynasty tom pod zmienioną nazwą: Annales Missiologici Posnanienses, którego zredagowali: Ambroży Andrzejak, Wojciech Kluj i Feliks Lenort. Kontynuacja tradycji wydawania najstarszego czasopisma misyjnego w Polsce została zachowana dzięki pomocy Fundacji, która od roku 2000 dofinansowuje tą publikację. Do końca 2010 r. subwencjonowała w ten sposób siedem tomów.

Dla uczczenia Międzynarodowego Akademickiego Kongresu Misyjnego, jaki odbył się między 28 września, a 2 października 1927 r. w Poznaniu, wydana została Jednodniówka. Broszura ta, w formie albumu liczy 184 strony i jest dwujęzyczna - polsko-francuska. Opatrzona została wstępem ks. kard. Augusta Hlonda, arcybiskupa diecezji gnieźnieńskiej oraz poznańskiej, prymasa Polski. Jej okładka, zarówno do wydania z 1927 r., jak i reprintu z 2007 r., który dofinansowany został przez Fundację Pomocy Humanitarnej Redemptoris Missio, nawiązuje do historii Kościoła w Polsce. W centrum widnieje wizerunek Czarnej Madonny, pod nim Chrystogram. Jak ze źródła, po lewej stronie wychodzą wizerunki świętych: Cyryla, Metodego, Wojciecha i królowej Jadwigi. Z prawej strony umieszczone zostały postacie: o. Benedykta Polonusa, św. Jacka OP, bł. Andrzeja Rumina i o. Hieronima Drzewickiego. Ramę natomiast tworzą herby wielkich ośrodków, opatrzone podpisami: Gniezno, Pomorze, Kraków, Warszawa, Lwów, Litwa oraz Poznań.

Jednodniówka ukazała się pod redakcją ks. Kazimierza Bajerowicza. Zagadnienia wstępne obejmują dział ilustracyjny prezentując wizerunki i biografie członków komitetu honorowego ${ }^{40}$ oraz wykonawczego ${ }^{41}$, dalej redaktorów i korespondentów, grupę kół akademickich i na końcu konferencjariuszy ${ }^{42}$. Po przedstawieniu programu całość zagadnienia podzielona została na sześć części.

${ }^{39}$ Zob. A. Szafran-Bartoszek, Bibliografia zawartości “Annales Missiologicae” 1928-1938, AMis 11 (2000), s. 265-291.

${ }^{40}$ W skład komitetu honorowego wchodzili: Ks. Kard. Abp A. Hlond, wojewoda - Hr. Bniński, rektor Uniwersytetu Poznańskiego - dr Grochmalicki, a marszałkiem kongresu był prof. Dembiński.

${ }^{41}$ Komitet wykonawczy reprezentowali: ks. Kan. Zborowski, ks. prof. Kowalski, bp Nowowiejski, o. Turowski i ks. K. Bajerowicz, a także biskupi i wikariusze generalni gnieźnieńscy i poznańscy: ks. infułat C. Meysner, bp A. Laubitz i bp K. Radoński.

${ }^{42}$ Konferencjariuszami Kongresu byli: abp de Guébriant, bp Baudrillart, ks. E. Kosibowicz, 
W części pierwszej zapoznać się możemy z katolicką literaturą misyjną okresu międzywojennego, istniejącymi w Polsce w tamtym okresie zakonami i zgromadzeniami zajmującymi się misjami, a także działającymi na terenie kraju akademickimi kołami misyjnymi. Część druga w całości poświęcona jest zakonom: benedyktynów, franciszkanów, karmelitów bosych, jezuitów i kapucynów. Rozdział trzeci i czwarty traktuje o zgromadzeniach zakonnych, osobno męskich i żeńskich. Przedostatnia część skupia się na pracy misyjnej w Niemczech, misjonarzach na Podlasiu i na odległych terenach misyjnych. Szósty rozdział pełni funkcję administracyjno - informacyjną i zawiera dodatkowo ilustracje kluczowych dla Poznania obiektów i miejsc.

W osiemdziesiątą rocznicę pierwszego wydania Jednodniówki, z uwagi na historyczno - misyjny charakter tej broszury, Fundacja Pomocy Humanitarnej Redemptoris Missio, postanowiła dofinansować, we współpracy z Wydziałem Teologicznym Uniwersytetu im. Adama Mickiewicza reprint cyfrowy tejże publikacji. Pośredniczy ona również w jej promowaniu i sprzedaży.

\section{Wystawy i spotkania}

Jednym ze sposobów ukazania osiągnięć czy też problemów, z jakimi borykają się misjonarze w różnych zakątkach ziemi są wystawy fotograficzne. Obraz, w sposób dogłębny trafia do naszej świadomości i jest doskonałym medium informacji. Fundacja chętnie przygotowuje wystawy pełne barwnych fotografii, które dokumentują działalność misyjno - medyczną polskich misjonarzy.

Wystawa jest nieodłącznym elementem dorocznych koncertów. Oglądają ją goście na holu auli uniwersyteckiej podczas przerwy. Plansze przekazują nie tylko podstawowe informacje o Fundacji, ale dokumentują konkretne działania. Nierzadko są to zdjęcia $z$ wakacyjnych praktyk studenckich, czy też wypraw medycznych, które ukazują wolontariuszy w trakcie udzielania świadczeń zdrowotnych. Przykładem tego typu wystawy jest stała ekspozycja zdjęć w Klinice Chorób Tropikalnych i Pasożytniczych, którą ukończono 19 listopada 2004 r. $^{43}$.

Pierwsza tego typu wystawa zorganizowana została w pierwszym półroczu 1994 r., w poznańskiej Farze ${ }^{44}$. Dotyczyła ona kilku ośrodków misyjnych i barwnie przedstawiała problemy medyczne w wybranych częściach świata. Kolejna wystawa fotograficzna przygotowana została z okazji przyjazdu o. Mariana Żelazka do Polski i odznaczenia go medalem Tym, którzy czyniq dobro.... Niezbęd-

prof. Schmidlin, ks. P. Charles, o. Woroniecki, o. Thauren Joh., o. Freitag, ks. Hugo Bertini, ks. Prof. Likowski, ks. Majkowski.

${ }^{43}$ Por. Z. Pawłowski, Fundacja pomocy humanitarnej Redemptoris Missio (Medicus Mundi Poland) 1992-2004, AMis 14 (2004), s. 221

${ }^{44}$ Por. tamże, s. 202. 
ne materiały, wolontariusze zgromadzili podczas wypraw medycznych i praktyk studenckich, które odbywały się w Ośrodku Leczenia Trędowatych w Puri. Wystawę pod tytułem: Na Indyjskiej Ziemi - 48 lat wśród Adibasów i Trędowatych, w Centrum Kultury Zamek, otworzył jej główny bohater - O. Marian Żelazek ${ }^{45}$. W czerwcu 1998 r. obejrzały ją rzesze poznaniaków. Na początku października tegoż roku, wystawę udostępniono do zwiedzania w Domu Polonii, w Warszawie. Jej otwarciu towarzyszyło wystapienie Prezesa Fundacji, Norberta Rehlisa, który przedstawił koleje powstania tej małej galerii, oraz wręczenia o. Marianowi Medalu Senatu Rzeczpospolitej Polskiej przez Alicję Grześkowiak (Marszałka Senatu). Uroczystość tę objął patronatem Prymas Polski, kard. Józef Glemp ${ }^{46}$. Rok później, w październiku 1999 r. pokazana została na Jasnej Górze, w klasztorze oo. paulinów, z okazji III Ogólnopolskiego Kongresu Misyjnego ${ }^{47}$. Przez pół roku wystawę o polskim misjonarzu, o. Marianie Żelazku gościły Niemcy. W Krefeld obejrzało ją tysiące naszych zachodnich sąsiadów ${ }^{48}$. W listopadzie o. Marian otworzył wystawę w poznańskim kościele pod wezwaniem św. Jana Bosko.

Ekspozycja wystawy $\mathrm{Na}$ Indyjskiej Ziemi..., odbyła prawdziwe tournée. W dniach 28.01 - 16.02.2001 r. wystawiona była w kościele św. Rodziny w Poznaniu, a w drugiej połowie lutego przewieziona została do Lublina, gdzie podczas V Forum Młodzieży Lubelszczyzny oglądały ją tysiące młodych, najpierw w lubelskiej filharmonii, a następnie, aż do maja obecna była w kościołach św. Stanisława i św. Rodziny. W pierwszych dniach czerwca pokazano ją w Kazimierzu Dolnym nad Wisłą gdzie odbywało się trzynaste Święto Młodych ${ }^{49}$. W dniach 1219 czerwca 2002 r. wystawiona została w Pałacu Opatów przy Muzeum Sztuki Współczesnej w Gdańsku, a później w Kościele Mariackim w Gdańsku. Wystawę obejrzeli również uczestnicy konferencji misyjnej zorganizowanej przez Salezjański Ośrodek Misyjny w Krakowie, dnia 24 października 2003 r. Od 1 lipca do 13 sierpnia wystawę o o. Marianie gościła Poznańska Archikatedra ${ }^{50}$.

Fundacja przygotowała także szereg innych wystaw. Przykładem niech będzie chociażby ekspozycja fotografii, ukazująca działalność Medicus Mundi International, z okazji jej zjazdu w dniach 30 czerwca - 2 lipca, w stolicy Wielkopolski $^{51}$. Innym przykładem była wystawiona $\mathrm{w}$ poznańskiej restauracji

${ }^{45}$ Por. A. Walkowiak, N. Rehlis, Stuga trędowatych..., "Raport" 1 (1998) nr 9, s. 2-3.

${ }^{46}$ Por. Wystawa w Warszawie, "Raport" 2 (1998) nr 10, s. 4.

${ }^{47}$ Por. Z. Pawłowski, Fundacja Redemptoris Missio (Medicus Mundi Poland) 1992-2004, AMis 14 (2004), s. 208.

${ }^{48}$ Por. Wystawa Fundacji w Niemczech, "Raport" 2 (2000) nr 14, s. 3.

${ }^{49}$ Por. Z. Pawłowski, Fundacja pomocy humanitarnej Redemptoris Missio (Medicus Mundi Poland) 1992-2004, AMis 14 (2004), s. 210-211.

${ }^{50}$ Por. tamże, s. 220.

${ }^{51}$ Por. N. Rehlis, Zjazd Medicus Mundi, "Raport” 2 (2000) nr 14, s. 2. 
Czerwony Fortepian galeria zdjęć, ukazująca przebieg Operacji Bangassu 2002 - jednej z największych wypraw medycznych zorganizowanych przez Fundację. Lekarz, Jan Czosnowski w taki sam sposób uwiecznił swoją posługę w ośrodku misyjnych w Chilandze. Wystawa relacjonująca jego pobyt w Zambii udostępniona została do oglądania, w kościele pod wezwaniem Matki Bożej Wspomożenia Wiernych w Swarzędzu ${ }^{52}$. Ogromnym powodzeniem cieszyła się wystawa przygotowana z okazji 10-lecia Fundacji. Pokazano ją m.in. w poznańskiej Farze, podczas dorocznego koncertu w 2002 r., w Szkole Podstawowej w Niepruszewie Puszczykowie, na osiedlu Chrobrego w Poznaniu. W 2003 r. pojawiła się w murach Klubu Seniora Starówka i Ośrodku Kultury w Pniewach, a w roku 2004 obejrzała ją społeczność szkolna Gimnazjum nr 12 w Poznaniu podczas misyjnych rekolekcji, które współorganizowali wolontariusze Fundacji ${ }^{53}$. Wystawa ta, promowała działalność Fundacji na Międzynarodowych Targach Poznańskich.

Ekspozycje fotograficzne to wizytówka promocyjna Fundacji. Organizowane są w szkołach, kościołach, klubach, ośrodkach kultury, podczas konferencji i sympozjów. Pojawiają się także przy okazji spotkań. Co roku odbywa się ich kilkanaście, a nawet kilkadziesiąt ${ }^{54}$. Wolontariusze chętnie dzielą się swoimi przeżyciami z młodzieżą szkół podstawowych, gimnazjalnych a nawet średnich. Bywa, jak to wcześniej zostało wspomniane, że spotkania te są urozmaiceniem szkolnych rekolekcji. Najczęściej połączone są z pokazem slajdów, które dokumentują ich pracę podczas wakacyjnych praktyk.

Ciekawą formą spotkania przedstawicieli Fundacji z lokalnym środowiskiem jest współorganizowany przez Fundację, Kongres Misyjny Dzieci. Pierwszy odbył się 28 maja 2008 r. i objął swoim zasięgiem Archidiecezję Poznańską. Wolontariusze Redemptoris Missio przybliżyli w formie zabaw ruchowych, pracy w grupach, ciekawych zadań i inscenizacji największy kontynent na Ziemi Azję ${ }^{55}$.

W dobie społeczeństwa informacyjnego szczególne miejsce spotkań z kulturą innych zakątków świata i problemami misji odegrały audycje radiowe. Po raz pierwszy program pod nazwą Misyjny Atlas Świata nadano 5 grudnia 2004 r., na antenie Radia Emaus. Audycje przygotowywali wspólnie przedstawiciele Fundacji i Akademickie Koło Misjologiczne Uniwersytetu im. Adama Mickiewicza. Program nadawany był dwa razy w miesiącu w niedzielne południe. Oprócz problemów medycznych, z jakimi borykają się misjonarze w ubogich krajach, dużo

${ }^{52}$ Por. Z. Pawłowski, Fundacja pomocy humanitarnej Redemptoris Missio (Medicus Mundi Poland) 1992-2004, AMis 14 (2004), s. 217.

${ }^{53}$ Por. tamże, s. 218.

${ }^{54}$ Sprawozdanie działalności Fundacji z 2006 r. podkreśla, że było ich (w 2006 r.) ponad 30.

${ }_{55}^{5}$ Por. A. Sill, Mali misjonarze, "Raport" 2 (2005) nr 29, s. 3. 
miejsca poświęcono teologii misji, a szczególnie nauczaniu papieża, Jana Pawła II ${ }^{56}$. Rocznie przygotowywanych było średnio dwadzieścia audycji, wydania specjalne redagowano na Niedzielę Misyjną. Tradycję Misyjnego Atlasu Świata podtrzymywano także w 2010 r. ${ }^{57}$.

Wiedza o misjach i misjonarzach przekazywania jest za pośrednictwem Fundacji na wiele sposobów. Wystawy, spotkania, koncerty czy filmy, a także audycje radiowe to doskonałe środki przekazu tych informacji. Zazwyczaj łączy się owe formy - koncertom towarzyszą wystawy, spotkaniom filmy itd. To istotnie wpływa na wzmocnienie przekazu i stwarza większą szansę na dotarcie do widza czy słuchacza. Fundacja ze swoją wystawa, filmem czy publikacją "puka" do ciekawych miejsc (kościołów, szkół, klubów seniora, na konferencje). Co ważne - nie zamyka swojej działalności jedynie w wielkopolskiej rzeczywistości. Dowodem na to jest także wysyłka Raportu i Medicus Mundi Polonia. Największym przedsięwzięciem w zakresie popularyzowania wiadomości o misjach i misjonarzach, a także działalności samej Fundacji jest bez wątpienia doroczny koncert. Stwarza możliwość osobistego spotkania, zobaczenia filmu o tematyce misyjnej albo relacji z praktyk. To w trakcie jego trwania można podziwiać barwne wystawy czy kupić książki. Jest on swoistym uzupełnieniem tego, czego nie znajdziemy na stronie internetowej i w przesyłanych przez Fundację biuletynach.

Zaznaczyć należy, że opisane powyżej płaszczyzny działalności Redemptoris Missio są jedynie wybranymi aspektami jej wszechstronnej aktywności. Fundacja podejmuje także szereg innych działań. Między innymi w trosce o misjonarzy, wolontariuszy i personel medyczny organizuje kurs: Opieka zdrowotna $w$ tropiku. W ten sposób włącza się w należyte przygotowanie tych, którzy udają się na misje.

Działalność Fundacji Pomocy Humanitarnej Redemptoris Missio jest doskonałym przykładem na to, że papieskie nauczanie można i trzeba realizować w praktyce. Daje ona budujące świadectwo o posłudze laikatu dla misji. Stanowi odpowiedź na wiele wyzwań i problemów podjętych przez Jana Pawła II. Jej zasług jest wiele... Wspiera dzieła charytatywne realizowane przez misjonarzy. Dba o pamięć o nich, poprzez popularyzowanie wiedzy o misjach i pracujących na całym świecie wolontariuszach i misjonarzach, tak duchownych jak i świeckich. Poprzez wielorakie inicjatywy uwrażliwia młode pokolenie na potrzeby misji. Zgodnie z papieskim zaleceniem wysyła nie tylko pomoc humanitarna, ale także organizuje pobyt dla młodzieży akademickiej i personelu medycznego w placówkach misyjnych.

${ }_{56}$ Por. Kalendarium Fundacji Pomocy Humanitarnej "Redemptoris Missio" w Poznaniu od października 2004 do końca roku 2005, AMis 15 (2006) s. 291.

${ }^{57}$ Por. A. Lipińska, Z Fundacji “Redemptoris Missio, MMP 10 (2010) nr 34/35, s. 3. 


\section{SUMMARY}

Foundation of the Humanitarian Aid „Redemptoris Missio” was established in 1992 r. in Poznañ. It is a fruit of the encyclical of John Paul II on the permanent validity of the Church's missionary mandate. The foundation forms the specialist medical backup for missionary centers. It organizes the medical and financial help as well as propagates the knowledge about missions and missionaries. It also carries a publishing activity. It gives a witness on the service of lay Christians in the missionary activities.

\section{Key words:}

Foundation of the Humanitarian Aid „Redemptoris Missio”, medical backup for missionary centers, "Medicus Mundi Polonia”, "Annales Missiologici Posnanienses"

\section{Słowa klucze:}

„Redemptoris Missio”, Fundacja Pomocy Humanitarnej „Redemptoris Missio”, zaplecze medyczne dla misji, „Medicus Mundi Polonia”, „Annales Missiologici Posnanienses” 